\title{
USING AFFINITY FOR TARGET GENERATION IN A FIREARMS TRAINING SIMULATOR
}

\author{
Vadim L. Khaikov \\ independent researcher, Krasnodar, Russian Federation, \\ e-mail: wadimhaikow@inbox.ru, \\ ORCID iD: (1)http://orcid.org/0000-0003-1433-3562
}

DOI: 10.5937/vojtehg67-22745; https://doi.org/10.5937/vojtehg67-22745

FIELD: Applied Mathematics

ARTICLE TYPE: Original Scientific Paper

ARTICLE LANGUAGE: English

\section{Abstract:}

The paper proposes a conversion of plane shooting targets using twodimensional affine transformations. It is assumed that affine transformations will be useful for target generation in firearms training simulators (FATS). The structure and the matrix formation algorithm of target vertex matrices are described as well as transformation matrices and output matrices. Vertex matrices were formed for twelve plane shooting targets. Transformation matrices $3 \times 3$ in size were used for conversions. Mathematical modelling and computer simulation of software-configurable plane shooting targets for FATS were performed in the Mathcad v.15 software.

Key words: shooting target, firearms training simulator, affine transformation, transformation matrix, Mathcad.

\section{Introduction}

A firearms training simulator (FATS) is a compound of hardware and software that creates augmented reality which can be used to improve shooting skills and rationalize behavior in such situations. Less often, a FATS is named a digital target range. The following shooting skills can be sharpened using a FATS: targets detection and classification; determination of a "shooter-target» distance; determination of target movement parameters; aiming and shooting; assessment of undershoot and overshoot parameters, and quick threat response. Along with a detailed description of an image transformation process in computer graphics systems (Rogers \& Adams, 1976), (Vince, 2012), (Hughes et al, 2013), a process of generating a software-configurable target of interest for a FATS is not described in scientific literature. Therefore, eliminating such a gap and explaining this procedure from a point of view of 
mathematics is a needful objective. A computer simulation of softwareconfigurable plane shooting targets for a FATS is performed in the Mathcad v.15 computer algebra system.

\section{Virtual landscape with targets}

A pistol (or a rifle) with a laser cartridge, a computer, one or more projectors and screens, specialized software, and a trained shooter are the basic elements of a FATS. A computer, a projector, a projector screen, and necessary software provide visualization of a virtual landscape (panorama) (Fig. 1). An important part of this panorama is a software-configurable shooting target which may be static or dynamic. The meaning of the term "virtual landscape with targets» should also be further clarified.

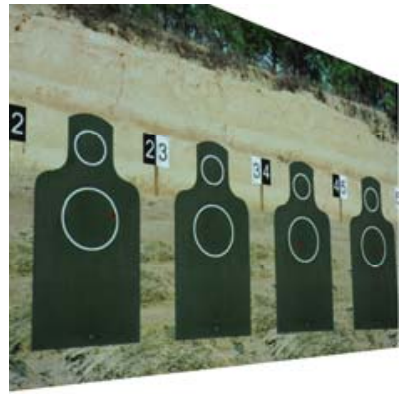

a)

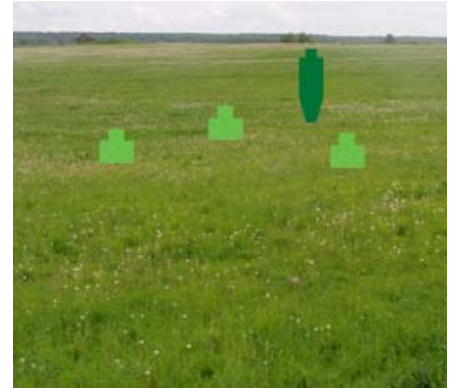

b)

Figure 1 - Virtual landscape with SGTs: a - with known "shooter-target» distance ${ }^{1}$, and $b-$ with unknown distance

Puc. 1 - Панорамы с программно-генерированными мишенями: $a-c$ известным расстоянием и $b-c$ неизвестным расстоянием

Слика 1 - Виртуелни пејзаж с компјутерски генерисаним метама: а - када је позната раздаљина између стрелца и мете, и б - када раздаљина није позната

A virtual landscape is usually characterized by a large depth of the visibility and a wide viewing angle (Fig. 1). Technically, it can be created by several LCD projectors. Unlike common shooting targets, made of paper, cardboard or metal plates, software-generated targets (SGTs) are part of a virtual landscape. We can say that, physically, they are a part of

${ }^{1}$ Fragment of a virtual lanscape (panorama) of a digital target range at the firearms training simulator in the Kunsan Air Base (Gunsan, the Republic of Korea) (Source: https://en.wikipedia.org/wiki/Shooting_target\#/media/File:A_digital_target_range_at_the_ firearms_training_simulator_on_Kunsan_Air_Base_waits_to_be_used.jpg) 
a screen at which a shooter aims and shoots during shooting practice and owing to which shooting performance effectiveness is analyzed. SGTs are generated by the program, visualized using a computer and displayed onto an LCD projector screen. Specialized FATS software should be able to visualize different types of SGTs and change their position in a virtual landscape.

For example, in Fig. 1a, four identical torso targets are placed side by side, their order is deterministic and the "shooter-target» distance is known in advance. Fig. $1 b$ presents four targets: three chest targets and one man-sized, arranged randomly and the "shooter-target» distance is not known in advance.

Since the dimensions of the same target change while increasing/decreasing the «shooter-target» distance, the controlled scaling of the target can create a visual illusion that a target is closer to or farther from a certain landmark. It should be added that a controlled change of a target's position can create an illusion of its movement. Thus, a computer program controls an influence on target geometry in order to create necessary visual illusions for a shooter.

From the point of view of planimetry, a SGT is a polygon, i.e. a geometrical figure bounded by a closed polygonal chain whose line segments do not intersect. Properties of a SGT as a planar geometric object are identified in (Khaikov, 2019a), (Khaikov, 2019b).

Affine transformation is a type of plane transformation, in which a straight line translates into a straight line, and parallel straight lines into parallel ones. Two-dimensional affine transformations are a class of mathematical transformations basic to modelling geometrical objects in the two-dimensional Cartesian coordinate system. Affine transformations of a target can be expressed by an analytical expression (by a formula). 2D affine transformation is carried out using matrix multiplication. The transformation matrix is multiplied by the target vertex matrix. As a result, we obtain the output matrix.

where

$$
\mathrm{TM} \times \mathrm{ATVM}=\mathrm{OM}
$$

$\mathrm{TM}$ - a transformation matrix,

ATVM - an augmented target vertex matrix (TVM) and $\mathrm{OM}$ - an output matrix.

Further on, each of these matrices is described in more detail. 


\section{Target vertex matrices}

A sequence of a target's vertices is their enumerated collection in which repetitions are not allowed. A TVM is a two-dimensional array that encodes a sequence of a target's vertices in the Cartesian coordinate system. The coordinates of twelve (Soviet/Russian and Swiss) targets are given in Tables 1-3. All dimensions in these tables are given in centimeters. The top (first) row of the TVM contains the coordinates of the abscissa $(x)$ and the second row - corresponding ordinates $(y)$ of each target's vertex. In this way, the coordinates of each vertex are written as a column vector $(2 \times 1$ submatrix). The vertices of polygons are listed in all cases counterclockwise. The first and third tables contain the data about ten frontal-attacking targets and the second table - about two flank-attacking targets. The rectangular arrays of numbers given in Tables 1-3 must be converted to the matrices of the appropriate size.

Table 1 - Coordinates of the vertices for the Soviet/Russian shooting targets

Таблица 1 - Координаты вершин силуэтов советских/российских стрелковых мишеней

Табела 1 - Координате врхова совјетских/руских мета за гађање

\begin{tabular}{|c|c|c|ccccccccc|}
\hline No. & $\begin{array}{c}\text { Types of } \\
\text { FRATs }\end{array}$ & $\begin{array}{c}\text { Number } \\
\text { of } \\
\text { target } \\
\text { vertices }\end{array}$ & \multicolumn{10}{c|}{ Coordinates of target vertices in the Cartesian } \\
coordinate system
\end{tabular}

Note: Target silhouettes are visualized in (Khaikov, 2019a, p.273)

\footnotetext{
${ }^{2}$ FRAT stands for a frontal-attacking shooting target
} 
Table 2 - Coordinates of the Swiss shooting targets

Таблица 2 - Координаты вершин силуэтов швейцарских стрелковых мишеней Табела 2 - Координате швајцарских мета за гађање

\begin{tabular}{|c|c|c|cccccccccc|}
\hline No. & $\begin{array}{c}\text { Types of } \\
\text { FRATs }\end{array}$ & $\begin{array}{c}\text { Number } \\
\text { of } \\
\text { target } \\
\text { vertices }\end{array}$ & \multicolumn{10}{c|}{ Coordinates of target vertices in the Cartesian } \\
coordinate system
\end{tabular}

Note: Target silhouettes are visualized in (Khaikov, 2019a, p.273)

Table 3 - Coordinates of the Soviet/Russian shooting (flank-attacking) targets Таблица 3 - Координаты советских/российских стрелковых (фрлангово-атакующих) мишеней

Табела 3 - Координате совјетских/руских ( бочних) мета за гађање

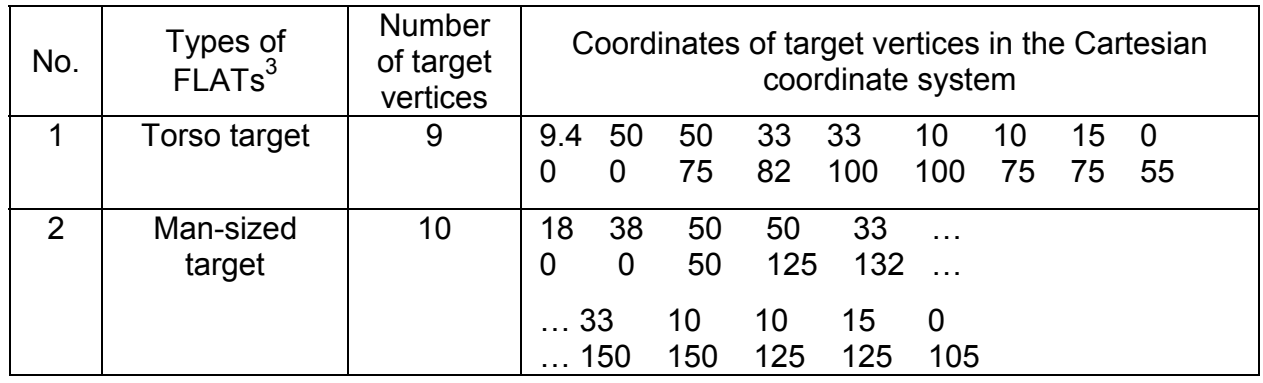

Note: Target silhouettes are visualized in (Khaikov, 2019b, p.527)

${ }^{3}$ FLAT stands for a flank-attacking shooting target 
To get an augmented TVM, we need to do three steps. To speed up the calculations, we will use the Mathcad software.

Step 1. A TVM is a two-dimensional array that encodes a sequence of a target's vertices in the Cartesian coordinate system. Each row of a TVM contains the coordinates of the abscissa $(x)$ and the ordinate $(y)$ of a target's vertex (initial TVM). A size of a TVM is $2 \times n$, where $n-$ total number of a target's vertices.

Step 2. The closure effect for a target's perimeter is realized by adding the first (initial) vertex to the right side of the final vertex. The vertices are traversed counterclockwise. To implement step 2, we must perform:

- set the ORIGIN variable

ORIGIN := 0

- first target's vertex

$\mathrm{FV}:=$ submatrix $(\mathrm{TVM}, 0,1,0,0)$

- obtain a closed TVM

$\mathrm{CM}:=$ augment(TVM, FV).

A size of a matrix with the closure effect is $2 \times(n+1)$.

Step 3. The augmented matrix is obtained by adding the third row of the ones with a size $(1 \times(n+1))$. To implement step 3 , we must perform:

- vector with numbers of vertices $\quad i:=0 . . n$

- matrix of ones $(G) \quad G_{i}:=1$

- the transpose of the $G$ matrix

- an array formed by placing $C M, G^{\top}$ top to

bottom is the augmented TVM $\operatorname{stack}\left(\mathrm{CM}, \mathrm{G}^{\mathrm{T}}\right)$

Now the size of the augmented TVM is $3 \times(n+1)$.

The functions «submatrix», "augment», "stack» and "origin» are built-in functions / variables of the Mathcad software (Maxfield, 2009).

Sets of TVMs can form libraries of shooting targets. Using the described principle, libraries of British (Clark, 2006), (Ministry of Defense of the UK, 2015), North American (Ministry of Defense of the USA, 2000), German (Ministry of Defense of the GDR, 1984), Polish (Ministry of Defense of the PPR, 1977), Soviet/Russian (Tarchishnikov, 2011), and other targets can be created.

\section{Affine transformation matrices}

Two-dimensional affine transformation matrices are used to apply linear transformation. Let us define simple affine transformation matrices that carry out only translation (shifting), scaling, shearing (skew), rotation and reflection. All enumerated matrices have a size of $3 \times 3$.

Simple 2D affine transformation matrices. Consideration of simple affine transformation matrices will begin with the operations of multiplication by the identity matrix, translating (shifting), and scaling. The description is accompanied by figures (Figs. 2-4) which show the type of 
the transformation matrix and its impact on the chest target. The initial target is shown in yellow. The target after affine transformation is blue.

Multiplication of the initial shape and the identity matrix does not change the initial target (Fig. $2 a)$. The submatrix $(2 \times 2)$ highlighted by the dotted line contains the basic elements of the transformation matrix.

The value of $X$ in the translate matrix produces a shift of an initial shape along the $0-x$ axis and the value of $Y$ determines the shift along the $0-y$ axis (Fig. 2b).

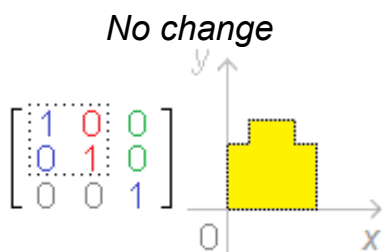

a)

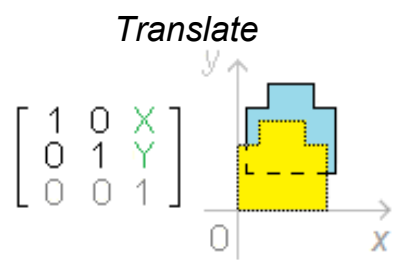

b)

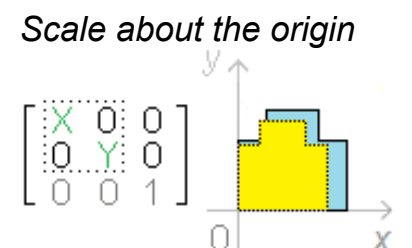

c)

Figure 2 - Transformation matrices and the results of their impact on the chest target: $a$ - unit matrix; $b$ - translation; $c$ - nonuniform scaling

Puс. 2 - Матрицы трансфрормации и результаты воздействия на грудную мишень: a - единичная мишень; $b$ - перенос; c-масштабирование Слика 2 - Трансформационе матрице и резултати њиховог утицаја на грудну мету: a - јединична матрица; б - транслација; в - неуниформно скалирање

Two-dimensional affine transformation can differentially scale a target (Fig. 2c). $X$ is a scale factor for the $0-x$ direction. $Y$ is a scale factor for the $0-y$ direction. If $X, Y$ is greater than zero, then a target will be increased, if less than zero, then it will be reduced. If $X=Y$, then uniform scaling takes place, but if $X \neq Y$, this is a non-uniform (differential) scaling.

Rotation of a target in two dimensions around the origin is carried out due to the rotation transformation matrix (Fig. 3a). Rotation is implemented at the angle $\theta$. If the angle $\theta$ is greater than zero, then the rotation takes place clockwise relative to the axis $0-y$, if less than zero, then it is counterclockwise. If the angle $\theta$ is 0 , then the transformation matrix turns into a unit matrix. Horizontal shear (or shear parallel to the 0 $x$ axis) is displacement of every point horizontally due to the horizontal shearing matrix (Fig. $3 b$ ). The slope of the vertical lines depends on the angle $\varphi$. If the angle $\varphi$ is 0 , then the shear transformation matrix turns into a unit matrix. Vertical shear (or shear parallel to the 0 -y axis) is displacement of every point horizontally due to the horizontal shearing 
matrix (Fig. 3c). The slope of the horizontal lines depends on the angle $\psi$. If the angle $\psi$ is 0 , then the shear transformation matrix turns into a unit matrix.

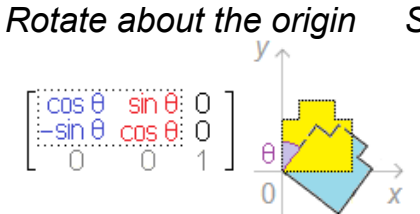

a)

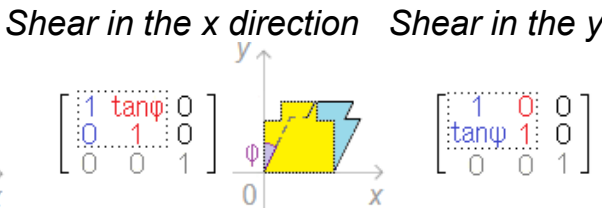

b)

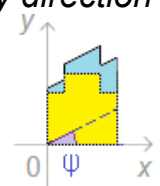

c)

Figure 3 - Transformation matrices and the results of their impact on the chest target: a - rotation; $b$ - horizontal shearing; $c$-vertical shearing

Puс. 3 - Матрицы трансформации и результаты воздействия на грудную мишень: $a$ - вращение; $b$ - горизонтальный сдвиг; c - вертикальный сдвиг Слика 3 - Трансорормационе матрице и резултати њиховог утицаја на грудну мету: а-ротација; б-смицање по х-оси; в - смицање по у-оси

If it is necessary to create a reflection target image, it is possible to multiply the reflection matrix with the target vertex matrices. The most spread reflection matrices are: reflection about the origin (Fig. 4a); reflection about the $0-x$ axis (Fig. $4 b$ ), and reflection about the $0-y$ axis (Fig. 4c).

\section{Reflect about the origin Reflect about the $x$-axis}

$\left[\begin{array}{cc:c}-1 & 0 & 0 \\ \hdashline 0 & -1 & 0 \\ \hdashline 0 & 0 & 1\end{array}\right]$

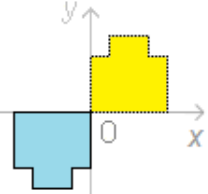

a)
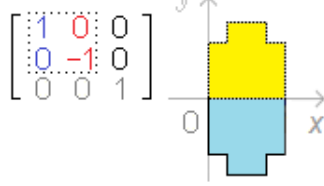

b)
Reflect about the y-axis

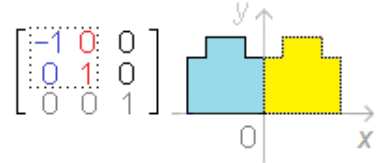

c)

Figure 4 - Three types of reflection transformation matrices and the results of their impact on the chest target

Puс. 4 - Три типа матриц преобразования отражений и результаты их воздействия на грудную мишень

Слика 4 - Три врсте трансформационих матрица рефрлексије и резултати њиховог утицаја на грудну мету

A $2 \times 2$ linear transformation matrix allows scaling, rotation, shearing, and reflection. A $3 \times 3$ linear transformation matrix provides translation. For the purpose of unification, the size of the transformation matrix is reduced to $(3 \times 3)$. 
2D composite affine transformation matrices. In contrast to the previously considered simple transformation matrices, composite matrices produce several elementary transformations simultaneously.

For example, if we need to translate, scale and rotate using only one matrix, we must first multiply them:

$$
\mathrm{CATM}=\operatorname{TrM} \times \mathrm{ScM} \times \mathrm{RoM},
$$

where

CATM - a composite affine transformation matrix,

TrM - a translating transformation matrix,

ScM - a scale transformation matrix and

RoM - a rotating transformation matrix.

As a result, we get

$$
\left[\begin{array}{lll}
1 & 0 & X \\
0 & 1 & Y \\
0 & 0 & 1
\end{array}\right] \times\left[\begin{array}{ccc}
X_{s} & 0 & 0 \\
0 & Y_{s} & 0 \\
0 & 0 & 1
\end{array}\right] \times\left[\begin{array}{ccc}
\cos (\alpha) & \sin (\alpha) & 0 \\
-\sin (\alpha) & \cos (\alpha) & 0 \\
0 & 0 & 1
\end{array}\right]=\left[\begin{array}{ccc}
X_{s} \cos (\alpha) & X_{s} \sin (\alpha) & X \\
-Y_{s} \sin (\alpha) & Y_{s} \cos (\alpha) & Y \\
0 & 0 & 1
\end{array}\right]
$$

Transforming a target shape using composite transformation matrices is not different from a corresponding transformation using simple transformation matrices. Like the previously selected one, a transformation matrix (simple or composite) must be multiplied by an ATVM.

\section{Output matrices}

The output matrix contains the coordinates of the vertices of the transformed matrix. This matrix has a size of $3 \times(n+1)$, where $n-$ total number of a target's vertices in the target which is taken as initial.

To obtain the TVM, in the first step, we need to separate, from the output matrix, the third row containing only ones. The resulting matrix will have a size of $2 \times(n+1)$. Next, we separate the last column of this matrix, as it repeats the first. This matrix will have a size of $2 \times n$. This is the desired matrix in which the first row contains the abscissas of the vertices, while the second row contains their ordinates.

\section{Target design in Mathcad}

After the creation of a library of targets (Tables 1-3) and transformation matrices and after the unification of their sizes, a simple 
simulation of two-dimensional affine transformation becomes possible. Let us give three examples of implementing affine transformation with targets of various types.

Example 1. We will perform uniform scaling. As the initial target, we take the Swiss chest target (Table 3 (No.3)). In order to increase the size of the target (Fig. 5a), we assign the scale factor $s=2$. The matrix multiplication process is presented below:

$$
\left(\left[\begin{array}{lll}
2 & 0 & 0 \\
0 & 2 & 0 \\
0 & 0 & 1
\end{array}\right] \times\left[\begin{array}{ccccccccc}
0 & 45 & 45 & 32.5 & 32.5 & 12.5 & 12.5 & 0 & 0 \\
0 & 0 & 30 & 35 & 55 & 55 & 35 & 30 & 0 \\
1 & 1 & 1 & 1 & 1 & 1 & 1 & 1 & 1
\end{array}\right]\right)^{T}=\left(\begin{array}{ccc}
0 & 0 & 1 \\
90 & 0 & 1 \\
90 & 60 & 1 \\
65 & 70 & 1 \\
65 & 110 & 1 \\
25 & 110 & 1 \\
25 & 70 & 1 \\
0 & 60 & 1 \\
0 & 0 & 1
\end{array}\right),
$$

where, the first $(3 \times 3)$ matrix - transformation matrix for uniform scaling; the second $(3 \times 9)$ matrix - the augment target vertices matrix; and the third $(9 \times 3)$ matrix - the output.

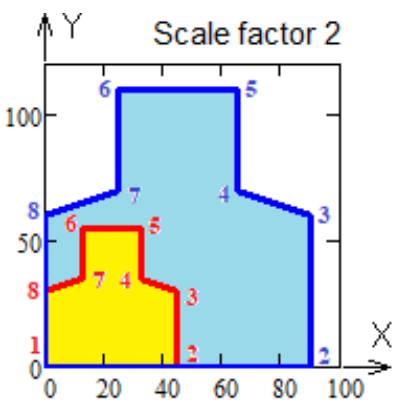

a)

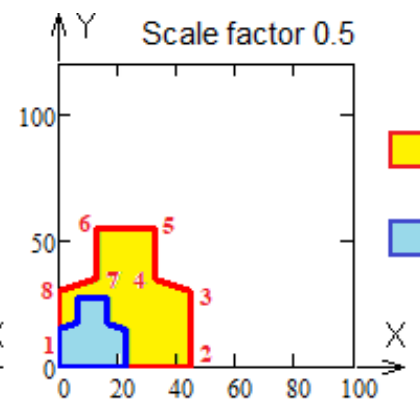

b) primary chest targets

chest targets after transformation

Figure 5 - Process of uniform scaling of the chest target using different values of $s$ Puc. 5 - Процесс маситабирования мишени с использованием разных значений $s$ Слика 5 - Поступак униформног скалирања грудне мете коришћењем различитих вредности $s$

To reduce the size of the chest target, select the parameter $=0.5$. The visualization of the results is shown in Figs. $5 a$ and $5 b$.

The perimeter of the initial matrix is colored in red. The perimeter of the transformed matrix is given in blue. Since the vertices of the matrices 
are numbered, we can see the directions of their movement during transformation. This kind of scaling can be used to calculate dry firing targets (Egloff, nd).

Example 2 - translating (shifting) of the Soviet/Russian FLAT (torso target, Table 4 (No.1)) with the shifting parameters: $X=60, Y=50$. The matrix multiplication procedure is shown below:

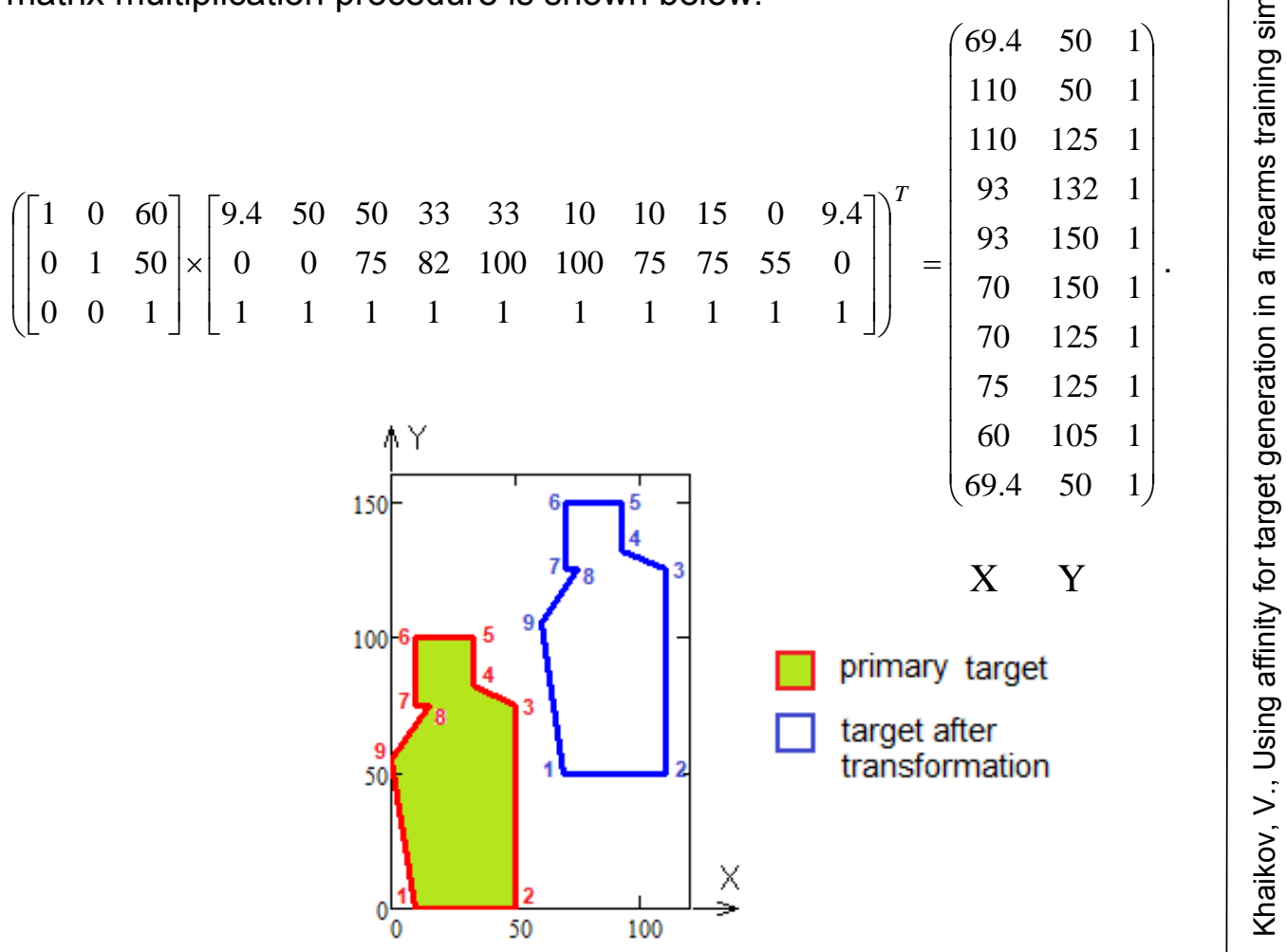

a)

Figure 6 - Target translating (shifting) process with different values of $X$ and $Y$ Puc. 6 - Процесс сдвигания мишени с использованием разных значений $X$ и $Y$ Слика 6 - Поступак транслације мете с различитим вредностима $X$ и $Y$

A graphical representation of the displacement is shown in Fig. $6 a$. The red border is the initial matrix and the blue border is the output matrix. Since the vertices of the matrices are numbered, we can see the parallelism of vertices movement.

Both in the first and second examples, the abscissas $(X)$ of the vertices are collected in the first column of the output matrix, and their ordinates $(Y)$ in the second column. 
Using translating (shifting), we can simulate the (right-left) movement of a target.

Example 3. It is an illustration of how matrix rotation is carried out in Mathcad. We used the Soviet/Russian head target (Table 1 (No.1)) for rotation. The rotation parameter (angle alpha) is a discrete variable with eight values: $\alpha=0, \pi / 4, \pi / 2,3 \pi / 4, \pi, 5 \pi / 4,3 \pi / 2$, and $7 \pi / 4$. The result of rotation is shown in Fig. 7 . Increasing the angle value from 0 to $7 \pi / 4$ gives the head target rotation clockwise relative to the origin.

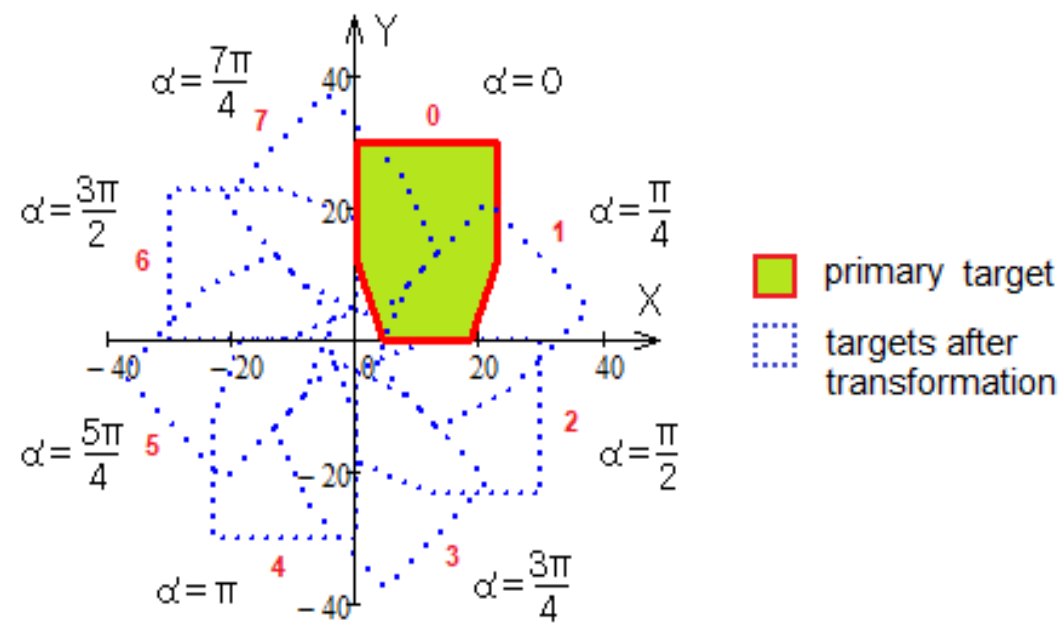

Figure 7 - Target rotating process using eight different angles

Pис. 7 - Процесс вращения мишени с использованием восьми углов поворота

Слика 7 - Поступак ротације мете коришћењем осам различитих углова

Swinging pendulum targets can be simulated using rotation.

\section{Conclusions}

Conversion of plane shooting targets is proposed using twodimensional affine transformations. A target library consisting of 12 shooting targets is proposed in this article. It is assumed that this type of conversion will be useful for specialized FATS software, where softwareconfigurable target generation is necessary. The matrices accompanying all stages of the conversion are described in detail: a target forming matrix, transformation matrices, and an output matrix. Mathematical modelling and computer simulation of software-configurable plane shooting targets for a FATS are performed in the Mathcad v.15 software. 


\section{References}

Clark, D. 2006. British targets from the mid 19th century to date: a shot history illustrating examples of rifle targets. Avalon Associates.

Egloff, M. Making dry firing targets. Available at: http://thecmp.org/makingdry-firing-targets/ [Accessed: 01 Juny 2019].

Hughes, J.F., Dam, A. Van, McGuire, M. et al. 2013. Computer Graphics: principles and practice. Addison-Wesley.

Khaikov, V.L. 2019a. Analysis of two groups of plane infantry targets as sets of geometric primitives. Vojnotehnički glasnik/Military Technical Courier, 67(2), pp.270-287. Available at: https://doi.org/10.5937/vojtehg67-20258.

Khaikov, V.L. 2019b. Analysis and synthesis of silhouettes of frontal- and flank-attacking shooting targets using graphs. Vojnotehnički glasnik/Military Technical Courier, 67(3), pp.525-537. Available at: https://doi.org/10.5937/vojtehg67-21754.

Maxfield, B. 2009. Essential Mathcad for Engineering, Science and Math. Academic Press.

-Ministry of Defense of the GDR. 1984. Zieldarstellung K 310/3/002. Berlin: NVA Landstreitkraftte (in German).

-Ministry of Defense of the PPR. 1977. Album Tarcz i figur bojowych. Warszawa: Wydawnictwo Ministerstwa Obrony Narodowej (in Polish).

-Ministry of Defence UK. 2015. Handbook of defence ranges safety (JSP 403). Volume 2. Chapter 29. Targetry. Available at: https://assets.publishing.service.gov.uk/government/uploads/system/uploads/att achment_data/file/138247/JSP403_Vol2_Chap29_DLRSC.pdf

-Ministry of Defence USA. 2000. Army field manual: tank gunnery training devices and usage strategies (FM 17-12-7). Chapter 10. Targets and Target Mechanisms. Available at: https://www.globalsecurity.org/military/library/policy/ army/fm/17-12-7/ch10.htm

Rogers, D.F., \& Adams, J.A. 1976. Matematical elements for computer graphics. McGraw-Hill Publishing Company.

Tarchishnikov, A.A. 2011. Kurs strel'b. Minsk: Belorusskiy natsional'nyy tekhnicheskiy universitet (in Russian). (In the original: Тарчишников, А.A. 2011. Курс стрельб. Минск: Белорусский национальный технический университет). Available at: https://rep.bntu.by/handle/data/960 [Accessed: 01 Juny 2019]

Vince, J. 2012. Matrix transforms for computer games and animation. Springer. 
ПРИМЕНЕНИЕ АФФИННОГО ПРЕОБРАЗОВАНИЯ ДЛЯ ГЕНЕРАЦИИ СТРЕЛКОВЫХ МИШЕНЕЙ В СТРЕЛКОВОМ ТРЕНАЖЁРЕ-ИМИТАТОРЕ

Вадим Л. Хайков

независимый исследователь, г. Краснодар, Российская Федерация

РУБРИКИ: 78.21.00 Военно-прикладные науки; 78.21.47 Баллистика. Теория стрельбы

ВИД СТАТЬИ: оригинальная научная статья ЯЗЫК СТАТЬИ: английский

\section{Резюме:}

Для трансформации плоскостных стрелковых мишеней предложено использовать афрфинные преобразования. Предполагается, что этот тип трансформации полезен при программной генерации мишеней в специализированном программном обеспечении тренажера, обучающего стрельбе из огнестрельного оружия. В статье приведено подробное описание матриц, сопровождающих этапы трансформации: от матрицы формирования контура стрелковой мишени, матрицы афффинного преобразования, до результирующей матрицы. Математическое и компьютерное моделирование программно-конфицурируемой мишени для стрелкового тренажёра выполнено в программном обеспечении Mathcad v.15.

Ключевые слова: стрелковая мишень, стрелковый тренажёримитатор, афоринное преобразование, матрица преобразования, Mathcad.

КОРИШЋЕЊЕ АФИНЕ ТРАНСФОРМАЦИЈА ЗА ГЕНЕРИСАЊЕ МЕТА У СИМУЛАТОРУ ЗА ОБУКУ У РУКОВАҢУ ВАТРЕНИМ OPУЖJEM

Вадим Л. Хајков

независни истраживач, Краснодар, Руска Федерација

ОБЛАСТ: примењена математика

ВРСТА ЧЛАНКА: оригинални научни рад

ЈЕЗИК ЧЛАНКА: енгЛески

Сажетак:

За гађање помоћу дводимензионалних африне трансформација у раду је предложена конверзија дводимензионалних мета. Пошло се од претпоставке да ће афине трансформације бити корисне за генерисање мета у симулаторима за обуку у руковању ватреним оружјем (FATS). За матрице врхова мета описани су структура $и$ алгоритам формирања матрица, 
трансформационе матрице. као и матрице излаза. Матрице врхова формиране су за дванаест дводимензионалних мета за гађање. За конверзију су коришћене трансорормационе матрице формата 3х3. За математичко моделирање и компјутерску симулацију софтверскигенерисаних дводимензионалних мета за гађање за FATS коришћен је софтввер Mathcad v.15.

Кључне речи: мета за гађање, симулатор за обуку у руковању ватреним оружјем, афине трансформација, трансформациона мampuца, Mathcad.

Paper received on / Дата получения работы / Датум пријема чланка: 05.08.2019. Manuscript corrections submitted on / Дата получения исправленной версии работы / Датум достављања исправки рукописа: 19.08.2019.

Paper accepted for publishing on / Дата окончательного согласования работы / Датум коначног прихватања чланка за објављивање: 21.08.2019.

(c) 2019 The Author. Published by Vojnotehnički glasnik / Military Technical Courier (www.vtg.mod.gov.rs, втг.мо.упр.срб). This article is an open access article distributed under the terms and conditions of the Creative Commons Attribution license (http://creativecommons.org/licenses/by/3.0/rs/).

(c) 2019 Автор. Опубликовано в «Военно-технический вестник / Vojnotehnički glasnik / Military Technical Courier» (www.vtg.mod.gov.rs, втг.мо.упр.срб). Данная статья в открытом доступе и распространяется в соответствии с лицензией «Creative Commons» (http://creativecommons.org/licenses/by/3.0/rs/).

(c) 2019 Аутор. Објавио Војнотехнички гласник / Vojnotehnički glasnik / Military Technical Courier (www.vtg.mod.gov.rs, втг.мо.упр.срб). Ово је чланак отвореног приступа и дистрибуира се у складу са Creative Commons лиценцом (http://creativecommons.org/licenses/by/3.0/rs/).

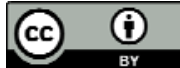

